\title{
Prevalence and Determinants of Pre-Hypertension among Undergraduate Preclinical Medical Students in Central Malaysia
}

\author{
Mohd Fauzi MF ${ }^{a, b}$, Mat Saruan NA ${ }^{a, b}$, Mohd Yusoff $H^{a}$, Mohd Tamil $A^{a}$ \\ ${ }^{a}$ Department of Community Health, Faculty of Medicine, Universiti Kebangsaan Malaysia Medical Centre, \\ Jalan Yaacob Latiff, Bandar Tun Razak, 56000 Cheras, Kuala Lumpur, Malaysia. \\ ${ }^{b}$ Ministry of Health Malaysia, Complex E, Federal Government Administrative Centre, 62590 Putrajaya, \\ Malaysia.
}

\section{ABSTRACT}

Introduction: Pre-hypertension, a classification of blood pressure ranging from 120-139 mm Hg systolic and/ or $80-89 \mathrm{~mm} \mathrm{Hg}$ diastolic, has been introduced to identify those high-risk group of developing hypertension to implement early intervention to halt disease progression. This study determines the prevalence of pre-hypertension and its determinants among undergraduate preclinical medical students in Malaysia. Materials \& Methods: This was a cross-sectional study conducted among 158 registered second year medical students at one research university in central Malaysia from January to April 2018. Results: The prevalence of pre-hypertension was $20.6 \%$ among undergraduate preclinical medical students. The most respondent was female (69.9\%), Malay ethnic (50.6\%) who had normal body mass index (67.3\%), no depression (79.5\%), no anxiety $(60.3 \%)$, no stress $(68.6 \%)$, low physical activity level $(44.9 \%)$, never smoked $(95.5 \%)$, and never consumed alcohol (87.8\%). Some respondents had positive family history of hypertension (43.6\%) and diabetis mellitus (31.4\%). After adjusted for all variables, gender ( $A O R=14.45,95 \% \mathrm{Cl} 5.58-37.43)$ and depression status (AOR=6.37, 95\% Cl 1.29-31.49) were significantly associated with pre-hypertension. Conclusion: The prevalence of pre-hypertension among preclinical medical students was lower compared to other country, predicted by gender and depression status. However, further comprehensive multicentered studies in Malaysia with larger sample size is recommended to get more precise results in identifying determinants for pre-hypertension so that early intervention could be implemented nationwide.

KEYWORDS: Pre-hypertension, determinant, medical student, Malaysia

\section{INTRODUCTION}

Hypertension is a well known predictors of cardiovascular and cerebrovascular disease ${ }^{1}$ which are among the major cause of death in Malaysia. ${ }^{2}$ Hypertension and its complications such as myocardial infarction, stroke, renal failure, and premature death are common medical conditions seen in primary healthcare ${ }^{3}$ and hospital setting. ${ }^{2}$ Globally, one-third of population had been affected. ${ }^{4}$ Similar evidence was recorded in Malaysia national survey which showed that one in three

Corresponding author:

Assoc. Prof. Dr. Azmi Mohd Tamil Department of Community Health, Faculty of Medicine,

Universiti Kebangsaan Malaysia Medical Centre Jalan Yaacob Latiff, Bandar Tun Razak

56000 Cheras, Kuala Lumpur, Malaysia

E-mail: drtamil@ppukm.ukm.edu.my
Malaysian adult had hypertension. ${ }^{5}$ However, despite health education and health awareness given by various agencies, the number of undiagnosed hypertension among 18 years old and above is still on the rising trend. ${ }^{5}$

In 2003, a new classification that includes the term 'pre-hypertension' has been introduced by the $7^{\text {th }}$ Joint National Committee on Prevention, Detection, Evaluation and Treatment of Hypertension, which is defined as blood pressure (BP) ranging from $120-139 \mathrm{~mm} \mathrm{Hg}$ systolic and/or 80-89 $\mathrm{mm} \mathrm{Hg}$ diastolic. ${ }^{6}$ Individual with prehypertension is at two- to threefold higher risk of developing hypertension as compared to optimal BP individual. $^{7}$ A cohort study published in 2001 revealed a conversion rate of $37 \%{ }^{8}$ while another study found higher conversion rate. ${ }^{9}$ The differences in conversion rates may be attributed to study 
duration, baseline BP and sociodemographic profiles. $^{7}$ The rationale for highlighting this new category of 'pre-hypertension' is to emphasize on the cardiovascular risk associated with BP in this range and to increase public health awareness on the preventive action. ${ }^{10}$ It was found that early identification of pre-hypertensive people and early intervention by adoption of healthy lifestyle could reduce the rate of progression to hypertension. ${ }^{11}$

Besides, it was found that hypertension is 'getting younger', which means that more younger people has been diagnosed with hypertension. The prevalence of pre-hypertension itself was found to be higher than hypertension among youth. ${ }^{12}$ Among Indian undergraduate medical students, the prevalence of pre-hypertension was ranging from $37.45 \%$ to $68.38 \%{ }^{13-15}$ and in Middle East, was $13.5 \%$ to $47.4 \% .{ }^{16-18}$ Among university students in ASEAN country, the overall prevalence of prehypertension was $19 \% .{ }^{19}$ In Malaysia, the prevalence of pre-hypertension among youth, particularly undergraduate students is ranging from $11.5 \%$ to $34.2 \%$. $^{20-21}$

The development of hypertension is due to multifactorial reasons that can be divided into modifiable and non modifiable factors. ${ }^{10,22}$ Modifiable factors includes dyslipidaemia, cigarette smoking, central obesity, microalbuminuria/ proteinuria and family history of premature cardiovascular disease. The risk is higher for individual with higher baseline BP, increasing age and obesity. Furthermore, the impact of treating patient with hypertension would result with much higher cost compared to early management of prehypertension. ${ }^{23}$ Thus, it is important to detect prehypertension among youth so that early intervention could be implemented to reduce the progression to hypertension. The aim of this study was to determine the prevalence of pre-hypertension and its determinants among second year medical students at a research university in central Malaysia.

\section{METHODOLOGY}

\section{Study design and population}

This was a cross sectional study conducted from January to April 2018 at one research university in central Malaysia. Based on previous studies among comparable population in Malaysia, the prevalence of pre-hypertension range $11.5 \%$ to $34.2 \% .^{20-21}$ Thus, the required sample size for precision of 0.05 based on previous prevalence studies ranged between 157 to 346 . We decided to employ a total 158 registered second year medical students, which met the minimum number of required sample size. We did not include the clinical medical students due to bureaucracy limitation in approaching them in the wards setting.

Moreover, during study period, some of them had been posted to district hospital and community setting which were not feasible for data collection in our limited capacity. On the other hand, the first year medical students were newly-enrolled, and still adapting with the study environment as medical students. Thus, we decided not to involve them as their adaptation process may confound the study outcome.

\section{Operational definition}

In this study, pre-hypertension was defined as BP reading ranging from $120-139 \mathrm{~mm} \mathrm{Hg}$ systolic and/or 80-89 mm Hg diastolic. ${ }^{6}$ Those respondents with systolic and diastolic less than $120 \mathrm{~mm} \mathrm{Hg}$ and 80 $\mathrm{mm} \mathrm{Hg}$, respectively were classified as normal BP; while those with systolic and/or diastolic more than $139 \mathrm{~mm} \mathrm{Hg}$ and/or $89 \mathrm{~mm} \mathrm{Hg}$, respectively were categorized as hypertension. ${ }^{6}$ For body mass index (BMI), the cut-off points for overweight and obesity were $25 \mathrm{~kg} / \mathrm{m}^{2}$ and $30 \mathrm{~kg} / \mathrm{m}^{2}$, respectively; while those with BMI less than $18.5 \mathrm{~kg} / \mathrm{m}^{2}$ were classified as underweight. ${ }^{24}$

Depression, anxiety and stress status were initially classified to normal, mild, moderate, severe and extremely severe based on score from 21-Items Depression, Anxiety and Stress Scale (DASS-21). ${ }^{25}$ In this study, normal level of depression, anxiety or stress were operationally defined as no depression or anxiety or stress, respectively. On the other hand, mild to extremely severe level of depression, anxiety or stress were collectively defined as having depression, anxiety or stress, respectively.

\section{Data collection}

Participation in the study was voluntary and participant can withdraw at any time. Data were collected by using self-administered questionnaires, calibrated weighing machine and calibrated Spirit CK 
-101C Mercurial Desk Model Sphygmomanometer. Questionnaires include sociodemographic data (age, gender, ethnicity, parental income, parental education), health-related data (past medical history, comorbid, family history, depression, anxiety, stress) and lifestyle-related data (smoking, alcohol consumption, physical activity). Depression, anxiety and stress status were measured by using Malay version of DASS- $21^{26}$ while level of physical activity was measured by using Malay version of short form International Physical Activity Questionnaire (IPAQ). ${ }^{27}$ Anthropometry and BP were measured by trained personnel. BP was measured according to American Heart Association (AHA) recommendation in sitting position twice at intervals of 1 minute, and the average results was used to represent respondents' BP. ${ }^{28}$ Before measurement, the positioning, cuff size selection, and brief explanation on the procedure were given to the respondents ${ }^{28}$. The respondents had been instructed not to talk or move during BP measurement. ${ }^{28}$

\section{Data analysis}

Data was analyzed by using SPSS version 21 . Descriptive analysis were performed and presented as frequencies and percentages. Simple logistic regressions were performed to test the association of socio-demographic, health-related and lifestylerelated factors with pre-hypertension. Data were presented as crude odds ratio (OR) and $\mathrm{p}$-value. Multiple logistic regression analysis were conducted to identify determinants of pre-hypertension among respondents. All independant variables were initially included and elimination was done by backward stepwise likelihood ratio (LR) test. Test for interaction and detection for multicollinearity was done. Next, Hosmer-Lemeshow goodness-of-fit test was conducted to assess the model fitting. Data were presented as adjusted OR (AOR) and p-value. Significant level for all relevant test was set at $\mathrm{p}<0.05$.

\section{RESULTS}

Out of 158 registered second year medical students, 156 of them voluntarily participated in this study which given the response rate of $98.73 \%$. Table 1 showed respondents' characteristic. Majority of them were female (69.9\%), Malay (50.6\%), B40 parental income group $(46.2 \%)$, normal BMI $(67.3 \%)$, no depression $(79.5 \%)$, no anxiety $(60.3 \%)$, no stress
(68.6\%), low physical activity level (44.9\%), never smoked (95.5\%) and never consumed alcohol (87.8\%).

Only one out of 156 respondents was known to have hypertension, and thus was excluded from bivariable and multivariable analysis. Prevalence of prehypertension among these 155 respondents with no known hypertensive status was $20.6 \%$.

Table 1: Respondents' characteristic

\begin{tabular}{|c|c|c|c|}
\hline $\begin{array}{l}\text { Variables } \\
(\mathrm{N}=156)\end{array}$ & $\begin{array}{l}\text { Frequency } \\
\text { (n) }\end{array}$ & $\begin{array}{l}\text { Percentage } \\
\text { (\%) }\end{array}$ & $\begin{array}{l}\text { Mean } \\
\text { (SD) }\end{array}$ \\
\hline $\begin{array}{l}\text { Age, years } \\
(\min 18 ; \max 21)\end{array}$ & & & $\begin{array}{l}19.9 \\
(0.6)\end{array}$ \\
\hline \multicolumn{4}{|l|}{ Gender } \\
\hline Male & 47 & 30.1 & \\
\hline Female & 109 & 69.9 & \\
\hline \multicolumn{4}{|l|}{ Ethnic } \\
\hline Malay & 79 & 50.6 & \\
\hline Chinese & 36 & 23.1 & \\
\hline Indian & 34 & 21.8 & \\
\hline Others & 7 & 4.5 & \\
\hline \multicolumn{4}{|l|}{ Parental Income } \\
\hline B40 (<RM3860) & 72 & 46.2 & \\
\hline $\begin{array}{l}\text { M40(RM3860- } \\
\text { RM8319) }\end{array}$ & 55 & 35.3 & \\
\hline T20 (> RM8319) & 29 & 18.6 & \\
\hline \multicolumn{4}{|l|}{$\begin{array}{l}\text { Hypertensive } \\
\text { Status }\end{array}$} \\
\hline $\begin{array}{l}\text { Unknown hyper- } \\
\text { tensive status }\end{array}$ & 155 & & \\
\hline $\begin{array}{l}\text { Known } \\
\text { hypertension }\end{array}$ & 1 & & \\
\hline \multicolumn{4}{|l|}{$\begin{array}{l}\text { Blood Pressure } \\
(n=155)^{b}\end{array}$} \\
\hline Normal & 123 & 79.4 & \\
\hline Pre-hypertension & 32 & 20.6 & \\
\hline $\begin{array}{l}\text { Body Mass Index, } \\
\mathrm{kg} / \mathrm{m}^{2}(\min 13.5 ; \\
\max 39.1)\end{array}$ & & & $\begin{array}{l}22.5 \\
(4.1)\end{array}$ \\
\hline Underweight & 18 & 11.5 & \\
\hline Normal & 105 & 67.3 & \\
\hline Overweight & 20 & 12.8 & \\
\hline Obese & 13 & 8.3 & \\
\hline \multicolumn{4}{|l|}{$\begin{array}{l}\text { Family History of } \\
\text { Hypertension }\end{array}$} \\
\hline Yes & 68 & 43.6 & \\
\hline No & 88 & 56.4 & \\
\hline \multicolumn{4}{|l|}{ Depression Status } \\
\hline $\begin{array}{l}\text { Normal (No } \\
\text { depression) }\end{array}$ & 124 & 79.5 & \\
\hline Mild - Moderate & 24 & 15.4 & \\
\hline $\begin{array}{l}\text { Severe - Very } \\
\text { Severe }\end{array}$ & 8 & 5.1 & \\
\hline \multicolumn{4}{|l|}{ Anxiety Status } \\
\hline $\begin{array}{l}\text { Normal (No } \\
\text { anxiety) }\end{array}$ & 94 & 60.3 & \\
\hline Mild - Moderate & 38 & 24.4 & \\
\hline $\begin{array}{l}\text { Severe - Very } \\
\text { Severe }\end{array}$ & 24 & 15.4 & \\
\hline \multicolumn{4}{|l|}{ Stress Status } \\
\hline $\begin{array}{l}\text { Normal } \\
\text { (No stress) }\end{array}$ & 107 & 68.6 & \\
\hline Mild - Moderate & 44 & 28.2 & \\
\hline $\begin{array}{l}\text { Severe - Very } \\
\text { Severe }\end{array}$ & 5 & 3.2 & \\
\hline
\end{tabular}




\begin{tabular}{cccc}
\hline Variables & Frequency & Percentage & Mean \\
$(\mathrm{N}=156)$ & $(\mathrm{n})$ & $(\%)$ & $(\mathrm{SD})$ \\
\hline
\end{tabular}

Level of Physical Activity

\begin{tabular}{|c|c|c|}
\hline Low & 70 & 44.9 \\
\hline Moderate & 52 & 33.3 \\
\hline High & 34 & 21.8 \\
\hline \multicolumn{3}{|l|}{ Smoking Status } \\
\hline Ever smoked & 7 & 4.5 \\
\hline Never smoked & 149 & 95.5 \\
\hline \multicolumn{3}{|l|}{$\begin{array}{l}\text { Alcohol } \\
\text { Consumption } \\
\text { Status }\end{array}$} \\
\hline $\begin{array}{l}\text { Ever consumed } \\
\text { alcohol }\end{array}$ & 19 & 12.2 \\
\hline $\begin{array}{l}\text { Never consumed } \\
\text { alcohol }\end{array}$ & 137 & 87.8 \\
\hline
\end{tabular}

Abbreviation: SD Standard deviation; B40 Below 40\%; M40 Middle 40\%; T20 Top 20\%

${ }^{a}$ excluded from logistic regression analysis

b excluded one respondent who was known to have hypertension
Table 2 showed distribution of pre-hypertension among respondents based on factors. Proportion of pre-hypertension in the respective group was higher among male $(51.1 \%)$, non-Malay $(23.4 \%)$, abovenormal BMI (33.1\%), no family history of hypertension (22.7\%), had family history of diabetes mellitus (28.6\%), severe-very severe depressive level (25.0\%), no anxiety $(28.7 \%)$, no stress $(23.6 \%)$, high physical activity level (29.4\%), ever smoked (57.1\%) and ever consumed alcohol (31.6\%).

Table 3 showed the factors associated with prehypertension among respondents using simple logistic regression and subsequently were run in multiple logistic regression to determine the determinants for pre-hypertension. There were no interaction and multicollinearity detected. The Hosmer-Lemeshow goodness-of-fit test showed that the model fits well. The model could predict $87.7 \%$ of those that will develop pre-hypertension correctly.

Table 2: Distribution of pre-hypertension among respondents

\begin{tabular}{|c|c|c|c|}
\hline \multicolumn{2}{|c|}{ Variables $(\mathrm{N}=155)^{\mathrm{a}}$} & \multicolumn{2}{|c|}{ Blood Pressure Classification } \\
\hline & & Normal, n (\%) & Pre-hypertension, n (\%) \\
\hline \multirow[t]{2}{*}{ Gender } & Male & $23(48.9)$ & $24(51.1)$ \\
\hline & Female & $100(92.6)$ & $8(7.4)$ \\
\hline \multirow[t]{2}{*}{ Ethnic } & Malay & $64(82.1)$ & $14(17.9)$ \\
\hline & Non-Malay & $59(76.6)$ & $18(23.4)$ \\
\hline \multirow[t]{3}{*}{ Body Mass Index } & Below Normal & $17(94.4)$ & $1(5.6)$ \\
\hline & Normal & $84(80.8)$ & $20(19.2)$ \\
\hline & Above Normal & $22(66.7)$ & $11(33.3)$ \\
\hline \multirow{2}{*}{$\begin{array}{l}\text { Family History of } \\
\text { Hypertension }\end{array}$} & Yes & $55(82.1)$ & $12(17.9)$ \\
\hline & No & $68(77.3)$ & $20(22.7)$ \\
\hline \multirow{2}{*}{$\begin{array}{l}\text { Family History of } \\
\text { Diabetes Mellitus }\end{array}$} & Yes & $35(71.4)$ & $14(28.6)$ \\
\hline & No & $88(83.0)$ & $18(17.0)$ \\
\hline \multirow[t]{3}{*}{ Depression Status } & Normal (No depression) & $93(75.6)$ & $30(24.4)$ \\
\hline & Mild-moderate & $24(100.0)$ & $0(0.0)$ \\
\hline & Severe-very severe & $6(75.0)$ & $2(25.0)$ \\
\hline \multirow[t]{3}{*}{ Anxiety Status } & Normal (No anxiety) & $67(71.3)$ & $27(28.7)$ \\
\hline & Mild-moderate & $33(89.2)$ & $4(10.8)$ \\
\hline & Severe-very severe & $23(95.8)$ & $1(4.2)$ \\
\hline \multirow[t]{3}{*}{ Stress Status } & Normal (No stress) & $81(76.4)$ & $25(23.6)$ \\
\hline & Mild-moderate & $37(84.1)$ & $7(15.9)$ \\
\hline & Severe-very severe & $5(100.0)$ & $0(0.0)$ \\
\hline \multirow{3}{*}{$\begin{array}{l}\text { Level of Physical } \\
\text { Activity }\end{array}$} & Low & $59(84.3)$ & $11(15.7)$ \\
\hline & Moderate & $40(78.4)$ & $11(21.6)$ \\
\hline & High & $24(70.6)$ & $10(29.4)$ \\
\hline \multirow[t]{2}{*}{ History of Smoking } & Ever smoke & $3(42.9)$ & $4(57.1)$ \\
\hline & Never smoke & $120(81.1)$ & $28(18.9)$ \\
\hline \multirow{2}{*}{$\begin{array}{l}\text { History of Alcohol } \\
\text { Consumption }\end{array}$} & Ever drinks & $13(68.4)$ & $6(31.6)$ \\
\hline & Never drinks & $110(80.9)$ & $26(19.1)$ \\
\hline
\end{tabular}

${ }^{\mathrm{a}}$ Excluding one known case of hypertension from total respondents of 156 
Table 3: Factors associated with pre-hypertension among respondents *

\begin{tabular}{|c|c|c|c|c|c|}
\hline \multirow[b]{2}{*}{ Variables $(\mathrm{N}=155)$} & \multicolumn{2}{|c|}{$\begin{array}{c}\text { SIMPLE LOGISTIC } \\
\text { REGRESSION }\end{array}$} & \multicolumn{3}{|c|}{ MULTIPLE LOGISTIC REGRESSION } \\
\hline & Crude OR & P-value ${ }^{b}$ & $\begin{array}{l}\text { Adjusted } \\
\text { OR }^{\mathrm{a}}\end{array}$ & P-value & $95 \% \mathrm{Cl}$ \\
\hline \multicolumn{6}{|l|}{ Gender } \\
\hline Male & 13.043 & $<0.001^{*}$ & 14.446 & $<0.001^{*}$ & $5.576,37.426$ \\
\hline Female & Ref. & & Ref. & & \\
\hline \multicolumn{6}{|l|}{ Ethnic } \\
\hline Malay & Ref. & & & & \\
\hline Non-Malay & 1.395 & 0.405 & & & \\
\hline \multicolumn{6}{|l|}{ Body Mass Index } \\
\hline Below Normal & Ref. & & & & \\
\hline Normal & 4.048 & 0.187 & & & \\
\hline Above Normal & 8.500 & 0.050 & & & \\
\hline \multicolumn{6}{|l|}{ Family Income } \\
\hline B40 & Ref. & & & & \\
\hline M40 & 1.372 & 0.230 & & & \\
\hline $\mathrm{T} 20$ & 1.873 & 0.487 & & & \\
\hline \multicolumn{6}{|c|}{ Family History of Hypertension } \\
\hline Yes & Ref. & & & & \\
\hline No & 1.348 & 0.464 & & & \\
\hline \multicolumn{6}{|l|}{ Depression Status } \\
\hline Normal (No depression) & 4.839 & $0.038^{*}$ & 6.370 & $0.008^{*}$ & $1.289,31.486$ \\
\hline Abnormal & Ref. & & Ref. & & \\
\hline \multicolumn{6}{|l|}{ Anxiety Status } \\
\hline Normal (No anxiety) & 4.513 & $0.004^{*}$ & & & \\
\hline Abnormal & Ref. & & & & \\
\hline \multicolumn{6}{|l|}{ Stress Status } \\
\hline Normal (No stress) & 1.852 & 0.188 & & & \\
\hline Abnormal & Ref. & & & & \\
\hline \multicolumn{6}{|l|}{ Level of Physical Activity } \\
\hline Low & Ref. & & & & \\
\hline Moderate & 2.235 & 0.107 & & & \\
\hline High & 1.475 & 0.411 & & & \\
\hline \multicolumn{6}{|l|}{ History of Smoking } \\
\hline Ever Smoke & 5.714 & $0.028^{*}$ & & & \\
\hline Never Smoked & Ref. & & & & \\
\hline \multicolumn{6}{|c|}{ History of Alcohol Consumption } \\
\hline Ever drink & 1.953 & 0.215 & & & \\
\hline Never drink & Ref. & & & & \\
\hline
\end{tabular}

\section{DISCUSSION}

The prevalence of pre-hypertension among preclinical medical students in this study was $20.6 \%$. This was lower compared to study done among undergraduates in Malaysia in $2014 . .^{21}$ This might due to the different in the sample size and reference population. Comparing with study done among undergraduates in other countries, the prevalence in this study was also lower. ${ }^{17-18}$ Underdiagnosis of pre-hypertension in Malaysia could be one of the reason as the number has been on the rise. ${ }^{5}$ However, the prevalence was higher when comparing with other Asian country. ${ }^{29}$ Coincide with the increased number of obesity among Malaysia population and the sedentary lifestyle practice nowadays, this figure alarms the nation as it can further predispose to hypertension. Awareness among them is crucial as this youngsters will grew up and lead the future generation. 
Respondents in this study which were the university students with mean age of 19.9 years could represent the youth of educated population in Malaysia. The mean age was comparable with other study done in Malaysia and the prevalence was actually reflect the decreasing number of prehypertension among the youth. ${ }^{21}$ Continuous health promotion and healthy activities organized by the Ministry of Health and private agencies must be sustainable to reduce the number further. On the other hand, early recognition and detection of prehypertension by health screening should be done to reveal the exact data or number of pre-hypertensive population for intensive intervention.

Besides that, this study showed that the proportion of pre-hypertension was significantly higher among male compared to female; male significantly had 14 times higher odds to have pre-hypertension as compared to female. This results concordance with other studies done among university students. ${ }^{17,21,29}$ The plausible explanation on this issue was supported by the gender difference in terms of hormonal activity e.g. estrogen hormone and metabolic rate at early age. ${ }^{30-31} \mathrm{~A}$ study by Everett and Zajacova (2015) among young adults found that gender differences in hypertension status was revealed at the age of as early as twenties, and female had higher hypertensive awareness contributed by higher healthcare use as compared to male. ${ }^{32}$

Other determinant in this study was depression status. In this study, those respondents with depression significantly had lower odds of having pre -hypertension. This result was contrast to the findings by other study which showed significant positive association between depression and prehypertension. ${ }^{21,33}$ However, there were studies that observed a significantly lower BP among depressive respondents, ${ }^{34-36}$ while another study among undergraduates student in one of the Asian country showed non-significant results. $^{26}$ The possible explanation for lower BP among depressed respondents is the central monoamine system through alteration of neuropeptide $Y$ as common factor in characterizing depressive symptoms, suppressing sympathetic activity and decrease BP. ${ }^{37}$ ${ }^{38}$ This could also be due to low sample size, and thus low study power.
The decision to conduct this study among medical students was not baseless; it was one of the strategy to combat hypertension as early as possible. As future health professionals or specifically medical doctors, maintaining good health status and early management of pre-disease state is crucial. This study revealed that $20.6 \%$ prevalence of prehypertension, and indirectly found that prevelance of depression, anxiety and stress were $20.5 \%, 39.8 \%$, and $31.4 \%$ respectively. Although these numbers seem to be small, it could increase when the stressor become higher in clinical years or housemanship training. Early intervention, for example selfresilient, may be required as nation need to have healthy doctors as role-model for their patients and community.

There were several limitations in this study. Due to the design of cross sectional, this study unable to detect temporal relationship or causality between the determinants and the outcome. For example, our study showed that depression status significantly determined pre-hypertension, however we cannot deduce the cause-effect relationship. Furthermore, although sample size met the calculated minimum requirement, it was the smallest that might limit the possibilities of detecting the significant difference results of certain determinants, and evident through wide confidence interval of our multivariable analysis.

\section{CONCLUSION}

In conclusion, the prevalence of pre-hypertension among undergraduates medical students was lower compared to other country, and gender and depression were the determinants. Since pre-hypertesion is an alarming pre-disease state nowadays especially among younger age group, early detection and screening at the age of 18 years is crucial as part of preventive intervention for hypertension. Prevention and control by collaboration between various sectors including parents are needed to promote healthy lifestyle for combating this disease. A further comprehensive multicenter studies in Malaysia should be conducted to get better understanding and precision in identifying risk factors for pre-hypertension so that early intervention could be implemented nationwide. 


\section{COMPETING INTEREST}

There is no conflict of interest.

\section{ACKNOWLEDGEMENTS}

The authors wish to thank Department of Community Health, Faculty of Medicine, Universiti Kebangsaan Malaysia and second year medical students of the study location for providing us cooperation to ensure success of this study.

\section{FUNDING SOURCE}

None

\section{REFERENCES}

1. Fagard RH, Celis $H$, Thijs $L$, Staessen JA, Clement DL, De Buyzere ML, De Bacquer DA. Daytime and Nighttime Blood Pressure as Predictors of Death and Cause-Specific Cardiovascular Events in Hypertension. Hypertension 2007; 51:55-61.

2. Ministry of Health Malaysia $(\mathrm{MOH})$. Health Facts 2018 (Reference Data for 2017). Ministry of Health Malaysia 2018. Available from: http:// www.moh.gov.my/resources/index/

Penerbitan/Penerbitan\%20Utama/

Fakta\%20kesihatan/

KM_HEALTH_FACTS_2018_new.pdf

3. James, P.A., Oparil, S., Carter, B.L., et al. Evidence-based guideline for the management of high blood pressure in adults: report from the panel members appointed to the eighth joint national committee (JNC 8). J Am Med Assoc. 2014; 311:507-520.

4. Mills KT, Bundy JD, Kelly TN, Reed JE, Kearney PM, Reynolds K, Chen J, He J. Global Disparities of Hypertension Prevalence and Control. Circulation 2016; 134(6):441-450.

5. Naing C, Yeoh PN, Wai VN, Win NN, Kuan LP, Aung K. Hypertension in Malaysia: An Analysis of Trends From the National Surveys 1996 to 2011. Medicine 2016; 95(2):e2417.

6. Chobanian AV, Bakris GL, Black HR, Cushman WC, Green LA, Izzo JL Jr, Jones DW, Materson BJ, Oparil S, Wright JT Jr, Roccella EJ, and the National High Blood Pressure Education Program Coordinating Committee. The seventh report of the joint national committee on prevention, detection, evaluation, and treatment of high blood pressure. Hypertension 2003; 42:1206-1252.
7. Doumas M, Katsiki N, Mikhailidis DP. Prehypertension, the Risk of Hypertension and Events. In: Zimlichman R et al., eds.

Prehypertension and Cardiometabolic Syndrome. Springer International Publishing AG, part of Springer Nature, 2019: 37-55.

8. Vasan RS, Larson MG, Leip EP, Kannel WB, Levy D. Assessment of frequency of progression to hypertension in nonhypertensive participants in the Framingham Heart Study: a cohort study. Lancet 2001; 358:1682-86.

9. Julius S, Nesbitt SD, Egan BM, Weber WA, Michelson EL, Kaciroti N, Black HR, Grimm RH, Messerli FH, Oparil S, Schork MA. Feasibility of Treating Prehypertension with an AngiotensinReceptor Blocker. New England Journal of Medicine 2006; 354:1685-1697.

10. Malaysian Society of Hypertension. Clinical Practice Guidelines: Management of Hypertension. 4th ed. Available from: http:// www.msh.org.my/ file_dir/20344308395be06dfdc3c01.pdf

11. Zhang W, Li N. Prevalence, Risk Factors, and Management of Prehypertension. International Journal of Hypertension 2011; 2011:605359.

12. Gyamfi D, Obirikorang $C$, Acheampong $E$, Danquah KO, Asamoah EA, Liman FZ, Batu EN. Prevalence of pre-hypertension and hypertension and its related risk factors among undergraduate students in a Tertiary institution, Ghana. Alexandria Journal of Medicine 2018.

13. Bhattacharjya J, Goswami B. Prevalence of Prehypertension among the Medical Students and its Correlation with Body Mass Index. Int J Sci Stud 2016; 4(7):13-16.

14. Shobha S Shetty and Avinash Nayak. Prevalence Of Prehypertension Amongst Medical Students In Coastal Karnataka. Journal of Evolution of Medical and Dental Sciences 2012; 1(6)

15. Chitrapu RV, Thakkallapalli ZM. Prehypertension among Medical Students and its Association with Cardiovascular Risk Factors. J NTR Univ Health Sci 2015; 4:8-12.

16. Soliman M, El-Salamony O, El-Khashab K, ElSherbiny NA, Khamis S. Study of hypertension among Fayoum university students. Int J Public Health Res. 2014; 2(2):15-9.

17. Al-Majed HT, Sadek AA. Pre-hypertension and hypertension in college students in Kuwait: a neglected issue. J Family Community Med. 2012; 19(2): 105-12. 
18. Koura MR, Al-Dabal BK, Rasheed P, AlSowielem LS, Makki SM. Prehypertension among young adult females in Dammam, Saudi Arabia. East Mediterr Health J. 2012; 18(7):728 $-34$.

19. Peltzer $\mathrm{K}$ et al. Prehypertension and psychosocial risk factors among university students in ASEAN countries. BMC Cardiovascular Disorders 2017; 17:230

20. Mohd Hafeez, I, Salmiah MS, Saliluddin SM. Pre -hypertension and its associated factors among students in a pre-university college in Malaysia. International Journal of Public Health and Clinical Sciences 2016; 3(5):2289. 7577.

21. Balami AD, Salmiah MS, Nor Afiah $M Z$. Psychological determinants of prehypertension among first year undergraduate students in a Public University in Malaysia. Malaysian Journal of Public Health Medicine 2014; 14(2):67-76.

22. Collier SR, Landram MJ. Treatment of prehypertension: lifestyle and/or medication. Vasc Health Risk Manag. 2012; 8:613-9

23. Chen T, Yu D, Cornelius V, Qin R, Cai Y, Jiang $Z$, Zhao Z. Potential health impact and cost-effectiveness of drug therapy for prehypertension. International Journal of Cardiology 2017; 240:403-408.

24. World Health Organization (WHO). Obesity: Preventing and managing the global epidemic. Report on a WHO Consultation on Obesity, Geneva, 3-5 June 1997. Geneva: WHO 1998.

25. Lovibond SH, Lovibond PF. Manual for the Depression Anxiety Stress Scales. (2nd. Ed.). Sydney: Psychology Foundation 1995.

26. Ramli M, Ariff MF, Zaini Z. Translation, validation and psychometric properties of Bahasa Malaysia version of the Depression Anxiety and Stress Scales (DASS). Asean J. Psychiatry 2007; 8(2):82-89.

27. Yee Chu AH, Moy FM. Reliability and Validity of the Malay International Physical Activity Questionnaire (IPAQ-M) Among a Malay Population in Malaysia. Asia Pacific Journal of Public Health 2015; 27(2): NP2381-NP2389.

28. Pickering TG, Hall JE, Appel LJ, Falkner BE, Graves J, Hill MN, Jones DW, Kurtz T, Sheps SG, Roccella EJ. Recommendation for blood pressure measurement in humans and experimental animals. Circulation 2005; 111 (5):697-716
29. Pengpid S, Peltzer K, Ferrer AJ.

Prehypertension and associated factors among university students in the Philippines.

International journal of adolescent medicine and health 2014; 26(2):245-52.

30. Ojeda NB, Grigore D, Robertson EB, Alexander BT. Estrogen protects against increased blood pressure in postpubertal female growth restricted offspring. Hypertension 2007; 50:679 -685 .

31. Hulanicka B, Lipowicz A, Kozieł S, Kowalisko A. Relationship between early puberty and the risk of hypertension/overweight at age 50: evidence for a modified Barker hypothesis among Polish youth. Econ Human Biol 2007;5:48-60.

32. Everett B, Zajacova A. Gender differences in hypertension and hypertension awareness among young adults. Biodemography and social biology 2015; 61(1):1-17.

33. Player MS, King DE, Mainous AG, Geesey ME. Psychosocial factors and progression from prehypertension to hypertension or coronary heart disease. The Annals of Family Medicine 2007; 5(5):403-11.

34. Hildrum B, Mykletun A, Stordal E, Bjelland I, Dahl AA, Holmen J. Association of low blood pressure with anxiety and depression: the Nord -Trondelag Health Study. J Epidemiol Community Health 2007; 61:53-58.

35. Hildrum B, Mykletun A, Holmen J, Dahl AA. Effect of anxiety and depression on blood pressure: 11 year longitudinal population study. Br J Psychiatry 2008; 193:108-113

36. Licht CMM, de Geus EJC, Seldenrijk A, van Hout HPJ, Zitman FG, van Dyck R, Penninx BWJH. Depression is associated with decreased blood pressure, but antidepressant use increases the risk of hypertension. Hypertension 2009; 53:631-638

37. Michalkiewicz M, Knestaut KM, Bytchkova EY, Michalkiewicz T. Hypotension and reduced catecholamines in neuropeptide $Y$ transgenic rats. Hypertension 2003; 21:1056-1062

38. Karl T, Herzog H. Behavioral profiling of NPY in aggression and neuropsychiatric diseases.

Peptides 2007; 28:326-333 